\title{
$\mathrm{NaY}$ 分子篎超笼内离子液体和金属配合物自组装制备溶剂分子 和金属配合物一体化催化剂
}

\author{
马昱博 ${ }^{1,2}$, 何昱德 ${ }^{1}$, 张庆华 ${ }^{1}$, 石 峰 $^{1}$, 马祥元 ${ }^{1}$, 卢六斤 ${ }^{1}$, 邓友全 ${ }^{1}$ \\ ${ }^{1}$ 中国科学院兰州化学物理研究所绿色化学与催化中心, 甘肃兰州 730000 \\ 2 中国科学院研究生院, 北京 100049
}

摘要: 采用自组装-瓶中造船法在 $\mathrm{NaY}$ 分子篎超笼内, 将溴化 1-癸基-3-甲基咪唑离子液体和邻菲罗啉钯组合成一体化催化剂, 并用于苯胺羰化反应. 结果表明, 相对于以离子液体为溶剂, 邻菲罗啉钯配合物/ $\mathrm{NaY}$ 分子篮为催化剂的体系, 该一体化催化剂 在离子液体和邻菲罗啉钯配合物用量显著降低的条件下, TOF 可达 $23000 \mathrm{~h}^{-1}$, 而相应均相催化剂体系的 TOF 仅为 $3060 \mathrm{~h}^{-1}$. 关键词：活性位；离子液体；金属配合物；羊化；苯胺；苯胺基甲酸甲酯；转化频率

中图分类号: 0643 文献标识码: A

\section{Self-Assembly of Ionic Liquids and Metal Complexes in Super-Cages of NaY: Integration of Free Catalysts and Solvent Molecules into Confined Catalytic Sites}

\author{
MA Yubo ${ }^{1,2}$, HE Yude ${ }^{1}$, ZHANG Qinghua ${ }^{1}$, SHI Feng ${ }^{1, *}$, MA Xiangyuan ${ }^{1}$, LU Liujin $^{1}$, DENG Youquan ${ }^{1, *}$ \\ ${ }^{I}$ Center for Green Chemistry and Catalysis, Lanzhou Institute of Chemical Physics, Chinese Academy of Sciences, \\ Lanzhou 730000, Gansu, China \\ ${ }^{2}$ Graduate University of Chinese Academy of Sciences, Beijing 100049, China
}

\begin{abstract}
The integration of a free metal complex, $\mathrm{Pd}(\mathrm{phen})^{2+}$, and a room temperature ionic liquid (IL) solvent molecule, 1-decyl-3-methyl imidazolium bromide, into a complete catalytically active site and confined in a NaY zeolite super-cage with an appropriate spatial arrangement was investigated. This integration was achieved through a molecular self-assembly method. A preliminary test of this catalyst system for the carbonylation of aniline to methyl phenyl carbamate indicated that far higher catalytic activity could be achieved (TOF increased from 3000 to $23000 \mathrm{~h}^{-1}$ ) with far lower amounts of the IL solvent and the Pd complex in comparison with a simple mixture of $\mathrm{Pd}($ phen $) \mathrm{Cl}_{2} / \mathrm{IL} / \mathrm{NaY}$ as the catalyst. This new system can also be applied to other areas of catalysis.

Key words: active site; ionic liquid; metal complex; carbonylation; aniline; phenyl methyl carbamate; turn over frequency
\end{abstract}

典型的均相催化体系通常由金属配合物催化剂 和溶剂组成, 其中溶剂作为反应介质对提高催化剂 活性具有重要作用。但我们推测, 在一个实际反应 中, 大部分溶剂分子仅仅起反应介质的作用, 少量具 有合适空间位置的溶剂分子有可能参与形成活性位 (见图 1(a)). 那么, 如果将溶剂分子和金属配合物固
定在适当的位置上, 就有可能使用少量溶剂就可形 成同样多的活性位 (见图 1(b)).

与有机溶剂相比, 离子液体具有低蒸气压和强 静电场等特点, 因而可用于均相催化剂体系 ${ }^{[1]}$. 近年 来, 人们将离子液体固载 ${ }^{[2,3]}$ 或包载在多孔材料中 ${ }^{[4]}$ 进行催化反应.

收稿日期: 2010-03-14.

联系人：石 峰. Tel/Fax: (0931)4968116; E-mail: fshi@licp.cas.cn

邓友全. Tel/Fax: (0931)4968116; E-mail: ydeng@licp.cas.cn

基金来源: 国家自然科学基金 (20533080).

本文的英文电子版(国际版)由 Elsevier 出版社在 ScienceDirect 上出版(http://www.sciencedirect.com/science/journal/18722067). 


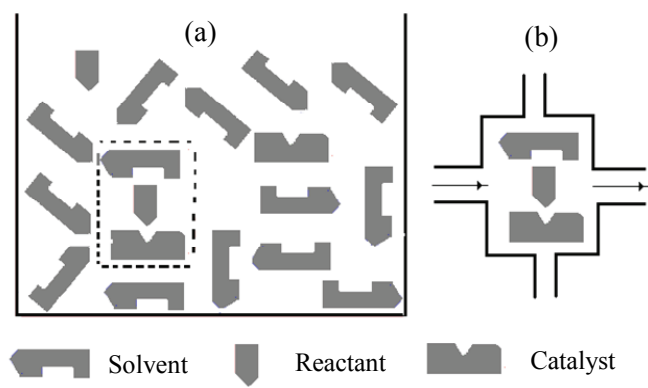

图 1 溶剂参与形成催化活性位 (a) 和空间限制下溶剂分子 与金属配合物形成催化活性位假想图 (b)

Fig. 1. Illustration of (a) a whole catalytically active site in a homogeneous reaction and (b) an isolated catalytically active site confined in a nano-pore.

因此, 本文尝试原位自组装-瓶中造船法 ${ }^{[5]}$, 将 1-癸基-3-甲基咪唑离子液体和邻菲罗啉钯配合物组 装在 NaY 分子篎的超笼内, 制得金属配合物和溶剂 分子一体化的催化剂. 首先将甲基咪唑、溴癸烷、 $\mathrm{Pd}^{2+}$ 和邻菲罗啉依次引入到 $\mathrm{NaY}$ 分子篎超笼中 (超 笼直径 $1.2 \mathrm{~nm}$, 通道直径 $\left.0.74 \mathrm{~nm}^{[6]}\right)$, 原位形成离子 液体和钯的邻菲罗啉配合物 (见图 2), 然后在自组 装材料间的相互作用下, 离子液体和邻菲罗啉钯配 合物分子可较为有序地分布于分子篮超笼中 ${ }^{[7]}$.

本文制备了 Pd-phen-NaY (邻菲罗啉钯被组装 于 $\mathrm{NaY}$ 分子篮超笼), Im- NaY (离子液体 1-癸基-3甲基咪唑被组装于 $\mathrm{NaY}$ 分子篮超笼), Pd-Im-NaY (钯和离子液体被组装于分子篮超笼) 和 Pd-phen-

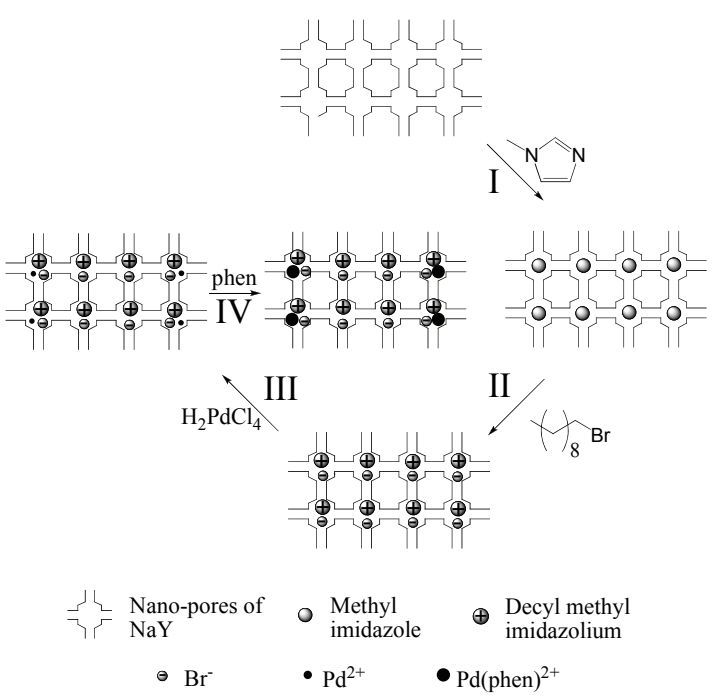

图 $2 \mathrm{NaY}$ 分子篮超笼中自组装/瓶中造船法合成离子液体 和邻菲罗啉钯示意图

Fig. 2. The process for the self-assembly of IL and Pd complex in the super-cage of $\mathrm{NaY}$.
Im-NaY (邻菲罗啉钯和离子液体被组装于分子篮超 笼) 四种催化剂. 为了便于比较, 本文还采用 Pdhen-NaY 浸渍离子液体的方法合成了 Pd-phenNaY-Im 催化剂.

Pd-phen-Im-NaY 催化剂的制备方法如下. 将 $10 \mathrm{~g}$ 的 $\mathrm{NaY}$ (Aldrich, 铝含量 6.8\%) 和 $25 \mathrm{ml}$ 甲基咪 唑依次加入到 $250 \mathrm{ml}$ 锥形瓶中, 在室温搅拌 $12 \mathrm{~h}$ 后, 加入 $75 \mathrm{ml}$ 溴癸烷, 在 $60^{\circ} \mathrm{C}$ 再搅拌 $12 \mathrm{~h}$ (甲基咪 唑和溴癸烷在使用前进行蒸馏处理). 将上述混合物 过滤, 用 $30 \mathrm{ml}$ 热乙醇洗三次, 可获得约 $11 \mathrm{~g}$ 的 $\mathrm{Im}-\mathrm{NaY}$ 样品. 将该样品加入到 $100 \mathrm{ml}$ 雉形瓶中, 再 加入 $30 \mathrm{ml}$ 蒸馏水和 $4.8 \mathrm{ml}$ 的 $\mathrm{H}_{2} \mathrm{PdCl}_{4}$ 溶液 $(0.028$ $\mathrm{mol} / \mathrm{L}$ ), 在室温搅拌 $12 \mathrm{~h}$ 后, 加入 $1 \mathrm{~g}$ 邻菲罗啉, 并 在室温下再摚拌 $12 \mathrm{~h}$. 最后将上述混合物过滤, 用 乙醇和丙酮洗涤, 在 $180^{\circ} \mathrm{C}$ 干燥 $3 \mathrm{~h}$, 即制得约 $10 \mathrm{~g}$ 的 Pd-phen-Im-NaY 催化剂.

样品的原子发射光谱 (3520 ICP AES) 结果表明, 制得催化剂中 $\mathrm{Pd}$ 含量为 $0.07 \% \sim 0.09 \%$. 红外光谱 (FT-IR) 结果表明, 催化剂 Im-NaY 在 1466 和 1571 $\mathrm{cm}^{-1}$ 处出现离子液体两个特征峰, 而它在 1169 $\mathrm{cm}^{-1}$ 处的特征峰被 $\mathrm{Si}-\mathrm{O}-\mathrm{Si}$ 的吸收峰覆盖. 这表明 在 $\mathrm{NaY}$ 分子篎超笼中原位形成了离子液体和钯的 邻菲罗啉配合物.

图 3 为各样品的拉曼 (Raman) (Nicolet 5700) 光 谱. 可以看出, Im-NaY 表现出与纯离子液体不同的 Raman 谱. 这是由于有机金属配合物和离子液体被 限制在纳米孔中, 可能导致分子对称性和几何结构 发生变化所致 ${ }^{[8,9]}$. 可见, 在 $\mathrm{NaY}$ 分子篎超笼中可能 形成了含有钯配合物和离子液体分子一体化催化 剂. 进一步的 FT-IR 和 Raman 结果表明, Pd-phen$\mathrm{NaY}$ 表现出与邻菲罗啉、氯化菲罗啉钯和 phen-NaY 催化剂不同的光谱特征. 这表明在 $\mathrm{NaY}$ 分子篮超 笼中形成了不同于氯化菲罗啉的钯配合物, 但其结 构还有待确定. 而 Pd-phen-Im-NaY 催化剂则表现 出和 Im-NaY 相同的 FT-IR 和 Raman 光谱特征. 这 可能是由于 $\mathrm{Pd}$ 担载量较低, 邻菲罗啉钯的光谱被离 子液体的所掩盖. 而 Pd-phen-NaY-Im 的 Raman 光 谱和离子液体的几乎一样, 但与 Pd-phen-Im-NaY 则 明显不同. 这表明 Pd-phen-NaY-Im 中的离子液体 处于 $\mathrm{NaY}$ 分子篎超笼的外部.

元素分析 (Elementar Vario EL) 结果表明, 这些 


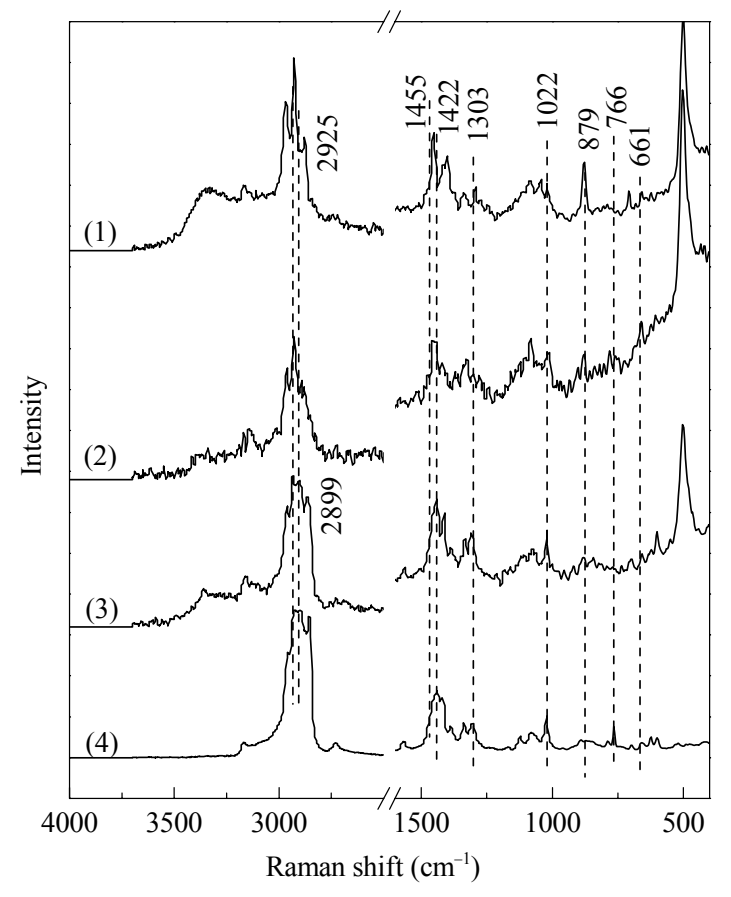

图 3 不同样品的 Raman 谱

Fig. 3. Raman spectra of different samples. (1) Pd-phen-Im-NaY; (2) Im-NaY; (3) Pd-phen-NaY-Im; (4) Im (1-decyl-3-methyl imidazolium bromide).

催化剂中离子液体含量为 $8.7 \% \sim 11.2 \%((1.7 \sim 2.2) \times$ $10^{20}$ 离子液体分子 $/ \mathrm{g}$ ). 在 Pd-phen-NaY 中, 邻菲罗 啉含量为 $0.2 \%\left(\sim 6 \times 10^{18}\right.$ 邻菲罗啉分子 $\left./ \mathrm{g}\right)$. 由于 $1 \mathrm{~g}$ 的 Pd-phen-Im-NaY 中含有 $2.6 \times 10^{20}$ 个超笼 ${ }^{[6]}$, 因 此每 100 个分子篎超笼中含 $65 \sim 85$ 个离子液体分 子, 仅 2.1 个钯配合物.

苯胺羰化反应是非光气合成异氰酸酯中间体的 一个重要方法, 而离子液体又是苯胺羰化反应的有 效溶剂 ${ }^{[10,11]}$. 因此, 本文以苯胺羰化为探针反应考 察了所合成催化剂的性能, 结果列于表 1. 可以看 出, 当以 Pd-phen-NaY 或 Pd-Im-NaY 为催化剂时, 苯胺转化率仅为 $27 \%$ 或 $21 \%$; 而以 Pd-phen-Im$\mathrm{NaY}$ 为催化剂时, 苯胺转化率达到 $81 \%$, TOF 值高 达 $23000 \mathrm{~h}^{-1}$. 当催化剂 Pd-phen-Im-NaY 用量由 50 $\mathrm{mg}$ 提高到 $100 \mathrm{mg}$ 时, 苯胺转化率可达 $95 \%$. 当以 Pd-phen-NaY-Im 为催化剂时, 苯胺转化率仅为 $10 \%$. 以机械混合的 $\mathrm{Pd}(\mathrm{phen}) \mathrm{Cl}_{2} / \mathrm{Im} / \mathrm{NaY}$ 为催化剂时, 苯 胺转化率为 $67 \%$, 而此时 $\mathrm{Pd}$ 和离子液体用量分别 为 Pd-phen-Im-NaY 催化剂时的 20 和 200 倍. 当重 复使用一次 Pd-phen-Im-NaY 催化剂时, 苯胺转化率 仍可达 $73 \%$.

\section{表 1 苯胺氧化羰化制备 $\mathrm{N}$-苯基氨基甲酸酯}

Table 1 Oxidative carbonylation of aniline over $\mathrm{NaY}$ confined Pd-ionic liquid catalysts to phenyl methyl carbamate

\begin{tabular}{ccccr} 
Entry & Catalyst & $\begin{array}{c}\text { Conversion } \\
(\%)\end{array}$ & $\begin{array}{c}\text { Selectivity } \\
(\%)\end{array}$ & $\begin{array}{c}\mathrm{TOF}^{\mathrm{c}} \\
\left(\mathrm{h}^{-1}\right)\end{array}$ \\
\hline 1 & Pd-phen-NaY & 27 & $\sim 99$ & 8500 \\
2 & Pd-Im-NaY & 21 & $\sim 99$ & 6600 \\
3 & Pd-phen-Im-NaY & 81 & $\sim 99$ & 23000 \\
$4^{\mathrm{a}}$ & Pd-phen-Im-NaY & 95 & $\sim 99$ & 13000 \\
5 & Pd-phen-NaY-Im & 10 & $\sim 99$ & 2400 \\
$6^{\text {b }}$ & Pd(phen)Cl $/$ Im/NaY & 67 & $\sim 98$ & 3060 \\
7 & Pd-phen-Im-NaY & 73 & $\sim 99$ & 20000 \\
\hline
\end{tabular}

Reaction conditions: catalyst $50 \mathrm{mg}$, aniline $1 \mathrm{ml}, \mathrm{MeOH} 5 \mathrm{ml}, \mathrm{CO} 5.5$ $\mathrm{MPa}, \mathrm{O}_{2} 0.5 \mathrm{MPa}, 150{ }^{\circ} \mathrm{C}, 1 \mathrm{~h}$; ${ }^{\text {ac }}$ catalyst $100 \mathrm{mg}$; ${ }^{\mathrm{b} d} \mathrm{Pd}(\mathrm{phen}) \mathrm{Cl}_{2} 1 \mathrm{mg}$, IL $1 \mathrm{ml}$, NaY 50 mg.

${ }^{c}$ Defined as the moles of substrate converted per mole of Pd per hour.

综上所见, 与 Pd-phen-NaY, Pd-Im-NaY 和机械 混合的 $\mathrm{Pd}$ (phen) $\mathrm{Cl}_{2} / \mathrm{Im} / \mathrm{NaY}$ 相比,一体化催化剂 Pd-phen-Im-NaY 表现出更高的催化苯胺氧化羰化 活性. 这表明离子液体和 Pd 配合物被固载于分子 篎超笼后, 其催化性能明显改善; 而高活性的催化 体系, 除了需要 Pd 配合物、离子液体和 $\mathrm{NaY}$ 之间的 协同作用外, 空间协同效应也是必需的. 结果还表 明, 钯、邻菲罗啉、甲基咪唑和溴癸烷可能在分子篮 超笼中原位形成了 $\mathrm{Pd}(\mathrm{phen})^{2+}$ 配合物和离子液体分 子, 且在分子篮超笼的作用下形成了高活性的活性 位, 而所形成活性位的数量约占分子篮所有超笼的 $2 \%$ 以下.

本文进一步对该催化剂进行了计算机模型化 (Forcite Plus/Materials Studio, Accelrys), 结果示于图 4. 结果表明, 在同一个分子笁超笼中组装一个离子 液体分子和一个 $\operatorname{Pd}(\text { phen })^{2+}$ 配合物是可能的. 离子 液体分子和 $\operatorname{Pd}(\text { phen })^{2+}$ 配合物平行分布, 两者之间

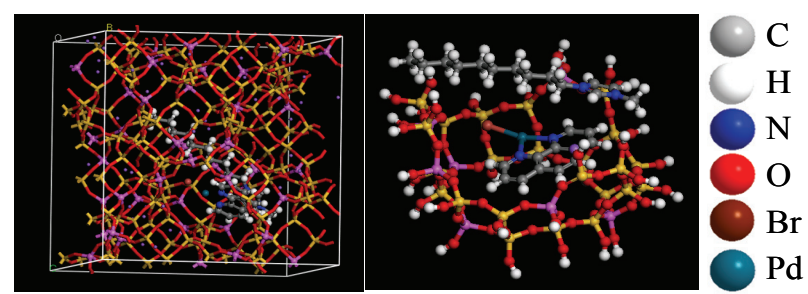

图 4 离子液体分子和 $\mathrm{Pd}(\mathrm{phen})^{2+}$ 在 $\mathrm{NaY}$ 分子篮超笼中的 空间排布

Fig. 4. The spatial arrangement of the ionic liquid molecule and the $\mathrm{Pd}(\text { phen })^{2+}$ complex in the super-cage of $\mathrm{NaY}$. 
有 $0.5 \sim 0.6 \mathrm{~nm}$ 的空间, 可满足分子篎超笼中反应物 和产物的传输.

综上所述, 本文采用自组装-瓶中造船法在 $\mathrm{NaY}$ 分子笁超笼内, 将离子液体分子和钯的邻菲罗啉配 合物组装成金属配合物和溶剂分子一体化催化剂. 用于苯胺氧化羰化反应时, 所使用的催化剂和溶剂 比常规均相反应时的更少, 而催化剂的活性更高. 该观念有助于其它反应催化剂的设计.

\section{致谢 作者对 NeoTrident 科技在计算机模拟方面的帮} 助表示感谢.

\section{参考 文 献}

1 Pârvulescu V I, Hardacre C. Chem Rev, 2007, 107: 2615

2 Valkenberg M H, DeCastro C, Hölderich W F. Green Chem, 2002, 4: 88

3 Mehnert C P, Cook R A, Dispenziere N C, Afeworki M. $J$ Am Chem Soc, 2002, 124: 12932

4 Shi F, Zhang Q H, Li D M, Deng Y Q. Chem Eur J, 2005, 11: 5279

5 Ulman A. Chem Rev, 1996, 96: 1533

6 Norman H, David R. C. Inclusion Chemistry with Zeolites: Nanoscale Materials by Design. Dordrecht: Kluwer Academic Publishers, 1995. 160

7 Lee J Y, Shou Z Y, Balazs A C. Phys Rev Lett, 2003, 91: 136103

8 Mintova S, De Waele V, Holzl M, Schmidhammer U, Mihailova B, Riedle E, Bein T. J Phys Chem A, 2004, 108: 10640

9 Shi F, Deng Y Q. Spectrochim Acta A, 2005, 62: 239

10 Kim H S, Kim Y J, Lee H, Park K Y, Lee C, Chin C S. Angew Chem, Int Ed, 2002, 41: 4300

11 Paul F. Coor Chem Rev, 2000, 203: 269

\section{英 译 文 \\ English Text}

A typical liquid homogeneous catalysis system generally consists of a transition metal complex and a solvent, in which the solvent as a reaction medium plays a very important role in achieving satisfactory catalytic performance. These solvent molecules may participate directly in the catalytic reaction as 'ligands' of the metal complex and this may establish an integrated or whole catalytically active site in addition to its role as a reaction medium. This means that only those solvent molecules located in an appropriate spatial position can participate in the formation of active sites with metal complexes (Fig. 1(a)). Large amounts of solvent molecules, however, are not a part of these active sites. Far fewer metal complexes and solvent molecules would be required if they are fixed at spatially appropriate positions (Fig. 1(b), or part of the dashed line in Fig. 1(a)).

Room temperature ionic liquids (RTILs) possess peculiar physicochemical properties such as very low vapor pressures and strong electrostatic fields in comparison with molecular liquids and they offer great opportunities to develop novel homogeneous catalysis systems [1]. Recently, the immobilization of RTILs onto solid supports [2,3] and the confinement of RTILs in porous materials [4] have been reported.

Herein, we report a new system wherein the integration of the free metal complex and the RTIL solvent molecule into a complete catalytically active site inside the super-cage of a $\mathrm{NaY}$ zeolite and with an appropriate spatial arrangement is achieved through molecular self-assembly (MSA) [5]. Initially, the IL (1-methyl-imidazole and decyl bromide) and metal complex $\left(\mathrm{Pd}^{2+}\right.$ and phenanthroline (phen)) fragments are successively introduced into the $\mathrm{NaY}$ super-cage (super-cage with a $1.2 \mathrm{~nm}$ diameter and channels with a $0.74 \mathrm{~nm}$ diameter [6]). The corresponding metal complex $\left(\operatorname{Pd}(\text { phen })^{2+}\right)$ and the IL (Im, 1-decyl-3-methyl imidazolium bromide) are then synthesized in situ, as shown in Fig. 2. Recent studies have suggested that synergistic interactions between self-organizing components and a self-assembling material can lead to hierarchically ordered structures; therefore, these Pd complexes and IL molecules are distributed in an orderly fashion in the NaY super-cage [7].

For comparison, several samples with slightly different loadings of Pd, ligand, and IL were prepared by MSA and these are denoted as Pd-phen-NaY, Im-NaY, Pd-Im-NaY, and Pd-phen-Im-NaY. Pd-phen-NaY-Im was also prepared by the impregnation of the assembled Pd-phen-NaY with the Im IL.

A typical procedure for the preparation of the catalyst Pd-phen-Im-NaY is as follows. A $10 \mathrm{~g}$ sample of $\mathrm{NaY}$ (Aldrich, aluminum content $=6.8 \%$ ) and $25 \mathrm{ml}$ methylimidazole were added to a $250 \mathrm{ml}$ round bottom flask and stirred at RT for $12 \mathrm{~h}$. Then, $75 \mathrm{ml}$ of decyl bromide was added and stirred at $60{ }^{\circ} \mathrm{C}$ for $12 \mathrm{~h}$. The methyl imidazole and decyl bromide were distilled before use. The mixture was filtered and washed 3 times $(30 \mathrm{ml} \times 3)$ with hot ethanol. A white solid powder $(\sim 11 \mathrm{~g})$ of Im-NaY was thus obtained and the $\mathrm{Im}-\mathrm{NaY}$ was transferred into a $100 \mathrm{ml}$ conical flask. Then, 30 $\mathrm{ml} \mathrm{H}_{2} \mathrm{O}$ and $4.8 \mathrm{ml} \mathrm{H}_{2} \mathrm{PdCl}_{4}$ solution $(0.028 \mathrm{~mol} / \mathrm{L})$ were added and stirred at RT for $12 \mathrm{~h}$. Finally, $1 \mathrm{~g}$ of phen was added and stirred at RT for another $12 \mathrm{~h}$. The reaction mixture was filtered and washed with ethanol and acetone, upon which it was dried at $180{ }^{\circ} \mathrm{C}$ for $3 \mathrm{~h}$ to obtain $\sim 10 \mathrm{~g}$ Pd-phen-Im-NaY. The other catalysts were prepared using a similar procedure.

Analysis by atomic emission spectrometry (3520 ICP AES) showed that Pd was successfully introduced into the 
$\mathrm{NaY}$ with varied loadings of $0.07 \%-0.09 \%$ for the different assembled samples. FT-IR characterization (Nicolet Nodule) showed that three characteristic peaks are present for the pure Im IL and two of them at 1466 and $1571 \mathrm{~cm}^{-1}$ were also observed for Im-NaY. The peak at $1169 \mathrm{~cm}^{-1}$ was overlapped by the strong $\mathrm{Si}-\mathrm{O}-\mathrm{Si}$ peak. This result indicated that an in situ formation of the Im ionic liquid occurred and this probably took place within the NaY super-cage. Raman characterization (Nicolet 5700) of the Im-NaY showed abnormal Raman spectra in comparison with the pure and bulk Im IL (Fig. 3).

This phenomenon was also observed when an organometallic complex [8] or an IL [9] was confined in nanoporous materials, which resulted from unusual changes in the symmetry and coordination geometry of the molecules confined in a nanoscale space. The FT-IR and Raman spectra of Pd-phen-NaY are quite different from that of free phenanthroline, $\mathrm{Pd}(\mathrm{phen}) \mathrm{Cl}_{2}$, and the assembled phen-NaY, which suggests that a different $\mathrm{Pd}$ complex forms in the $\mathrm{NaY}$ but its structure is not clear at this stage. For Pd-phen-Im-NaY, the same FT-IR and Raman spectra as for $\mathrm{Im}-\mathrm{NaY}$ are observed and the characteristic peaks of the Pd complex could not be observed because of the overlapping IL peaks and the low loading of Pd. The Raman spectrum of Pd-phen-NaY-Im is almost the same as that of pure Im IL but quite different from that of Pd-phen-Im-NaY suggesting that the Im IL in Pd-phen-NaY-Im was not incorporated into the super-cage of the $\mathrm{NaY}$ zeolite.

Elemental analysis (Elementar Vario EL) showed that the IL concentration in all these samples was between $8.7 \%$ and $11.2 \%$ (or $\sim(1.7-2.2) \times 10^{20}$ IL molecules $/ g$ ). The phenanthroline content in Pd-phen-NaY was $\sim 0.2 \%$ (or $6 \times 10^{18}$ phenanthroline molecules/g). Because there are $2.6 \times 10^{20}$ super-cages per gram of Pd-phen-Im-NaY (pore volume $\approx$ $0.34 \mathrm{ml} / \mathrm{g}, 1.3 \mathrm{~nm}$ diameter pores) [6], the ratio of IL molecules/super-cages $\approx(65-85) / 100$ and the ratio of $\mathrm{Pd}$ atoms/super-cages $\approx 2.1 / 100$.

The carbonylation of aniline is an important process for the phosgene free synthesis of isocyanate, and RTILs is effective in these reactions $[10,11]$. Therefore, aniline carbonylation was selected as a model reaction to test the catalysts (Table 1). For the synthesis of methyl phenyl carbamate (MPA) from aniline, the Pd-phen-NaY and Pd-Im-NaY catalysts had lower activity (entries 1 and 2). Pd-phen-Im$\mathrm{NaY}$ greatly increased the catalytic activity and the TOF reached $23000 \mathrm{~h}^{-1}$ (entry 3), while the conversion reached $95 \%$ when more catalyst was used (entry 4). However, only $\sim 10 \%$ conversion was obtained for Pd-phen-NaY-Im (entry 5 ). The catalysts prepared by self-assembly had much higher catalytic activity than the simple mixture of $\mathrm{Pd}$ (phen) $\mathrm{Cl}_{2} / \mathrm{Im} / \mathrm{NaY}$ (entry 6) although $\sim 200$ times more ionic liquid and $\sim 20$ times more $\mathrm{Pd}$ were used in $\mathrm{Pd}$ (phen) $\mathrm{Cl}_{2} / \mathrm{Im} / \mathrm{NaY}$. Furthermore, the reuse of Pd-phenIm-NaY gave a $73 \%$ conversion (entry 7 ), which indicated that the reuse of this catalyst system is possible.

Based on the fact that the catalytic activity of Pd-phenIm-NaY was far higher than that of Pd-phen-NaY, $\mathrm{Pd}-\mathrm{Im}-\mathrm{NaY}$, and the simple mixture of $\mathrm{Pd}$ (phen) $\mathrm{Cl}_{2} / \mathrm{Im} / \mathrm{NaY}$, we suggest that the enhanced catalytic activity results from the formation of an integrated or a whole catalytically active site consisting of the $\mathrm{Pd}(\mathrm{phen})^{2+}$ complex and the Im IL in an appropriate spatial arrangement within the super-cage of $\mathrm{NaY}$. Therefore, a synergism between the Pd complex, the $\mathrm{IL}$, and $\mathrm{NaY}$ is necessary, and this spatial synergism is required for enhanced catalytic performance. The reaction results also suggest that in addition to the introduction of $\mathrm{Pd}$, phenanthroline, methyl imidazole, and decyl bromide into the $\mathrm{NaY}$ and the in situ formation of $\mathrm{Pd}(\mathrm{phen})^{2+}$ and Im IL, both the $\mathrm{Pd}(\text { phen })^{2+}$ and the Im IL can incorporate into the same NaY super-cage with an appropriate spatial arrangement although these integrated catalytic sites are few (less than $2 \%$ of $\mathrm{NaY}$ super-cages).

Computer modeling (Forcite Plus/Materials Studio, Accelrys) indicated that the self-assembly of an Im IL molecule and a $\mathrm{Pd}(\text { phen })^{2+}$ complex in the same super-cage of $\mathrm{NaY}$ was possible and a suitable spatial arrangement was also calculated (Fig. 4). The Im IL and the $\operatorname{Pd}(\text { phen })^{2+}$ were located in parallel positions within the super-cage. The computer model also revealed that some space $(0.5-0.6 \mathrm{~nm}$ between the planes of the phenanthroline and the imidazolium rings) exists for reactant transportation.

In conclusion, a novel method for the integration of a free metal complex and a RTIL molecule into a NaY zeolite super-cage, which formed an effective catalytic site, was developed by molecular self-assembly. Far higher catalytic activity was achieved for the carbonylation of aniline using much lower amounts of ionic liquid as a solvent and less metal complex as well. This new system can be applied to other areas of catalysis.

\section{Acknowledgements}

We thank NeoTrident Technology Limited for helping with computer modeling.

Full-text paper available online at ScienceDirect http://www.sciencedirect.com/science/journal/18722067 